\title{
Survival of Black- eyed Susan from Different Regional Seed Sources under Low and High Input Systems
}

\author{
James J. Marois and \\ Jeffrey G. Norcini
}

\begin{abstract}
Additional INDEX WORds.native wildflower, ecotype, Fusarium oxysporum, methyl bromide, Rudbeckia bivta
\end{abstract}

Summary. Survival of black-eyed susan (Rudbeckia birta) from three regional seed sources was evaluated after inoculation with the pathogenic fungus Fusarium oxysporum in the greenhouse, and after they were planted in fumigated or nonfumigated and irrigated or nonirrigated field plots. The three seed sources were northern Florida (NFL), central Florida (CFL), or Texas (TEX). Plants from the three seed sources were inoculated individually under greenhouse conditions with four isolates of $F$. oxysporum originally isolated from the roots of diseased black-eyed susan grown in ecotype trials near Monticello, Fla. About 20\% of the inoculated plants developed symptoms similar to those observed in the field, but no consistent ecotype or isolate effects were observed. In the field trial, planting beds were fumigated with methyl-bromide and chloropicrin and irrigated with drip irrigation (high input), not fumigated and irrigated, fumigated and not irrigated, or not fumigated and not irrigated (low input). During the first month of the trial, treatment and seed source had a significant effect on survival due to the low initial survival of NFL in the nonfumigatednonirrigated plots. After the first month, only seed source had a

University of Florida, Institute of Food and Agricultural Sciences, North Florida Research and Education Center, 155 Research Rd., Quincy, FL 32351.

Florida Agricultural Expt. Station journal series R 08727. We thank Frank Martin for assistance in the experimental design, and Matthew Vargas and Jim Aldrich for their technical assistance. 
significant effect on survival, with TEX decreasing rapidly and the NFL population decreasing to a lesser degree. The decline of TEX could not be directly attributed to pests or climatic effects.

$\mathrm{B}$ lack-eyed susan is a wild flower that occurs throughout much of the United States (Rickett, 1967), including Florida (Wunderlin, 1998). It occurs naturally in open, upland conditions as well as flatwoods (Wunderlin, 1998), and frequently grows in disturbed sites like roadsides. The U.S. Dept. of Agriculture-NRCS(2001)classifies black-eyed susan as annual/biennial/perennial; Florida ecotypes have been observed to be annuals to shortlived perennials (unpublished data). Flowering is from late spring through fall, depending on the climate.

Because of its showy flowers, black-eyed susan is often selected for roadside wildflower plantings. This has resulted in commercial seed production and distribution systems of lines that have been selected for specific desirable characteristics. This selection process and the identification of known ecotypes of the species (Beckwith, 1991; Celik, 1996; Norcini et al., 1998) may have affected how well specific lines perform under differing environmental conditions.

Norcini et al. (1998, 2001b) reported that a northern Florida ecotype and a central Florida selection from a native population survived longer under Florida conditions [American Horticultural Society (AHS) Heat Zone 9; USDA Hardiness Zone 8b] than a commercially produced selection from Texas. None of the Texas plants survived through October (most did not survive through September), whereas $60 \%$ and $90 \%$ of northern Florida and central Florida plants were still alive in October, and 20\% and 90\% of northern Florida and central Florida plants, respectively, were alive in $\mathrm{No}^{-}$ vember when the experiment was terminated. For several years researchers also observed that the commercially produced Texas selection consistently senesced in August in low input gardens at the North Florida Research and Education Center in Monticello (unpublished observations). Researchers hypothesized that the differences in plant survival may have been due to the better adaptation of the Floridaderived plants to the environmental conditions of Florida.

Differences in responses to biotic and abiotic stresses as affected by seed source have been noted for other native wildflower species grown under Florida conditions. Greater incidence of disease and/or foliar decline occurred on lanceleaf coreopsis (Coreopsislanceolata) and lyreleaf sage (Salvia lyrata) derived from non-Florida seed sources compared to Florida ecotypes (Norcini et al., 1998). In a later study (Norcini et al., 2001a), percent survival of a Florida ecotype of lyreleaf sage was higher than the non-Florida selection. Likewise, plants of a nonFlorida selection of blanketflower (Gaillardia pulchella) grown under low input conditions senesced by midAugust whereas most plants of a Florida ecotype survived through mid-October (Norcini et al., 1998).

The primary objective of this study was to determine what mechanisms might be responsible for the more rapid decline of the Texas selection of black-eyed susan under Florida conditions. A secondary objective of the study was to determine if chemical soil fumigation and/or irrigation might increase survival of black-eyed susan under northern Florida conditions.

\section{Materials and methods}

Plant material. Three different seed sources of black-eyed susan were used, the same as used by Norcini et al. (200lb) in previous work. The northern Florida ecotype (NFL) was derived from seed collected in 1997 from native populations growing in upland pine forests of the Red Hills region of the Florida panhandle and southern Georgia (AHS Heat Zone 9; USDA Hardiness Zone 8b) and later increased (Norcini et al., 1999). A central Florida selection (CFL) of black-eyed susan originated from seed of a native population growing in a mesic area of eastern Sarasota County, Fla. (AHS Heat Zone 10; USDA Hardiness Zone 9a). The CFL used in this study was derived from container-grown plants propagated from seed increased at the North Florida Research and Education Center in Monticello, Fla. (AHS Heat Zone 9; USDA Hardiness Zone $8 \mathrm{~b})$. The third seed source was a largeflowered selection of a Texas ecotype (TEX) produced by Wildseed Farms, Fredericksburg, Texas (AHS Heat
Zone 9; USDA Hardiness Zone 8a).

Pathogen isolation. Populations of plants from the three seed sources were established in 1998 at the North Florida Research and Education Center in Monticello, Fla. (lat. $30.5 \mathrm{~N}$, long. $83.9 \mathrm{~W}$, AHS Heat Zone 9, USDA Hardiness Zone $8 \mathrm{~b}$ ) as part of a larger study to compare the performance of the CFL, NFL, and TEX at different locations in Florida (Norcini et al., 2001b). Seeds were sown in Metro-Mix 220 (Scotts Co., Marysville, Ohio) in cell packs, fertilized weekly after first true leaves appeared with $\mathrm{N}$ at $50 \mathrm{ppm}\left(\mathrm{mg} \cdot \mathrm{L}^{-1}\right)$ (15N-13.2P-12.4K, Peters 15-3015, Scotts Co., Marysville, Ohio), and once with trace elements (DynaGreen at $530 \mathrm{ppm}$ A.H. Hummert, St. Louis, Mo.). Seedlings were transplanted in March on $2-\mathrm{ft}(0.6-\mathrm{m})$ centers in a completely randomized design (10 single plant replications per seed source) to a site that was previously in turfgrass. Glyphosate was used to kill the existing turfgrass. Plants were located in areas about 8.7 inches $(22 \mathrm{~cm})$ in diameter from which dead turfgrass was removed. The plot was mulched with 2 to 4 inches $(5$ to $7.6 \mathrm{~cm}$ ) of pine straw. Weeds were removed manually, and plants were irrigated as necessary.

Stem and root samples were taken from dead or dying plants on which wilting occurred on specific branches (along with leaf chlorosis) while the rest of plant appeared healthy; about $50 \%$ of plants that were in decline exhibited these symptoms. This wilt symptom suggested attack of the roots by Fusarium since there were no obvious foliar pathogens or insects associated with the decline of these plants. Plant parts were surface sterilized in $10 \%$ sodium hypochlorite $(\mathrm{v} / \mathrm{v})$ for 1 min and plated onto half strength potato dextrose agar (PDA) (Difco, Detroit, Mich.).

Pathogenicity tests. Greenhouse experiments were conducted to determine if the Fusarium oxysporum that was isolated from the plants mentioned above (see Pathogen IsolaTION in Results and Discussion) might have influenced survival of NFL, CFL, and TEX. It was hypothesized that if TEX proved to be more severely affected by the fungus than NFL or CFL, then it might explain some of the decreased survival rates noted in field plots (Norcini et al. 1998, 2001b, unpublished observations). Plants from 
each seed source were inoculated with one of four isolates of $\mathrm{F}$. oxysporum. Plants were started as previously described and transplanted to 6 inch ( 15 $\mathrm{cm}$ ) pots containing Fafard Mix No. 2 (Conrad Fafard, Inc., Agawam, Mass.). After 2 weeks the roots were cut 1 inch $(2.5 \mathrm{~cm})$ from the main stem with a 4 inch-long knife, and $1.7 \mathrm{fl} \mathrm{oz}(50 \mathrm{~mL})$ of a $3.0 \times 10^{6}$ conidia/fl oz $\left(10^{5}\right.$ conidia/mL) spore suspension from one of the four isolates was poured into the cuts in the soil. Deionized water was used for the noninoculated control. The spore suspension was washed from plates of 2 -week-old cultures of the isolates grown on half strength PDA at room temperature $\left[\left(70{ }^{\circ} \mathrm{F}\left(21^{\circ} \mathrm{C}\right)\right]\right.$ and under lights. After 12 weeks the number of plants with wilt symptoms or death was recorded. Each isolate treatment was distributed in a randomized complete block, with five plants per block for each seed source. The experiment was conducted twice, with inoculations in March and August of 2000. The greenhouse temperature was maintained at 75 to $90{ }^{\circ} \mathrm{F}\left(23.9\right.$ to $\left.32.2^{\circ} \mathrm{C}\right)$, and plants were irrigated daily as needed.

Field study. In 2001, a field experiment was conducted to further determine the impact of specific environmental parameters on survival of the plants from the three seed sources. The plots were established at the North Florida Research and Education Center in Quincy, Fla. on a Dothan sandy loam (fine loamy siliceous, thermic Plinthic Kandiudults) soil. Plots were beds that were 6 inches high $\times 33$ inches wide $(15.2 \times 83.8 \mathrm{~cm})$. The treatments were 1) fumigated with methyl bromide and irrigated with drip irrigation (high input), 2) fumigated with methyl bromide and not irrigated, 3) not fumigated and irrigated, and 4 ) not fumigated and not irrigated (low input). Methyl bromide-chloropicrin $(67 \% / 33 \%, \mathrm{v} / \mathrm{v})$ at $350 \mathrm{lb} /$ acre $\left(392 \mathrm{~kg} \cdot \mathrm{ha}^{-1}\right)$ was applied to strip fumigated plots via three chisels at 8 inches $(20.3 \mathrm{~cm})$ deep and spaced 12 inches $(30.5 \mathrm{~cm})$ apart. Fumigated beds were then immediately sealed with black polyethylene mulch. The mulch was removed weeks 3 weeks later at planting on 12 Apr. 2001. The treatments were planted with NFL, CFL, and TEX in a complete block design, with five replicates per seed source and five plants per replicate. Transplants were produced as before. The area was fer- tilized with a broadcast application of 13N-1.8P-10.8K (13-4-13 bulk fertilizer) at $1500 \mathrm{lb} / \operatorname{acre}\left(1681 \mathrm{~kg} \cdot \mathrm{ha}^{-1}\right)$ before bedding.

Plants were irrigated as needed with drip tubing buried 3 inches (7.6 $\mathrm{cm}$ ) deep and 6 inches off center. Weekly from 9 July through 3 Sept., the number of plants surviving was recorded. Survival data were analyzed as a nested design, with the varieties nested within the treatments utilizing SAS V8.01 (SAS Institute, Cary, N.C.). The daily minimum and maximum temperature of the soil at a depth of 4 inches and air at 60 inches $(1.5 \mathrm{~m})$ were also recorded from 9 July to 3 Sept.

\section{Results and discussion}

Pathogen isolation. There was no obvious vascular discoloration in the stem tissue. The most common fungus isolated was F. oxysporum, which was consistent with the wilt symptoms previously described. Some isolates are known plant pathogens, but other isolates are saprobes in soil and on plant debris. The pathogenicity of the wilt causing isolates is also very specific, with an individual strain (pathotype) often able to infect only one species or subspecies (Booth, 1971).

Pathogenicity tests. Less than $20 \%$ of the inoculated plants developed symptoms similar to those described previously, with no differences in percentage of plants that developed symptoms among NFL, CFL, and TEX (results not shown). The wilting and leaf chlorosis followed by root rot was similar to that previously observed in the field. Lack of a significant impact of the $F$. oxysporum inoculations on plant survival could have been due to environmental conditions of the greenhouse, potting mix, or method of inoculation. There also was no significant effect of isolate on symptom development or survival of inoculated plants (results not shown). We concluded that although the fungal pathogen F. oxysporum may play a supporting role in the decline of the plants during the season, it was not a primary one, at least under the conditions tested. Of those plants that did show symptoms, it was possible to reisolate the fungus from the stems and roots.

Field study. Survival of NFL, CFL, and TEX was affected by the treatments during the beginning of the experiment; however, by the middle of Aug. the treatment effect was no longer significant (Table 1). Seed source affected survival throughout the experiment. The significant effect of treatment early in the season was due in large part to the poor rate of survival in the nonirrigated/ nonfumigated treatment, where initial stand establishment was significantly lower than in the other treatments (Table 1). This effect, however, ended by the middle of Aug. when the survival of TEX dropped dramatically (Table 1). Dead or dying plants, regardless of seed source, exhibited symptoms similar to those observed previously.

The daily maximum and minimum air and soil temperatures did not differ significantly during July and Aug. (Fig. 1), indicating that a differential survival response to heat stress by CFL, NFL, and TEX was probably not involved. The average daily maximum and minimum air temperatures in July were 88 and $75^{\circ} \mathrm{F}\left(31\right.$ and $\left.24^{\circ} \mathrm{C}\right)$, respectively. The average daily maximum and minimum air temperatures in August were 88 and $72{ }^{\circ} \mathrm{F}$, respectively. The average daily maximum and minimum soil temperatures in July were 82 and $81{ }^{\circ} \mathrm{F}$ ( 28 and $\left.27^{\circ} \mathrm{C}\right)$, respectively. The average daily maximum and minimum soil temperatures in August were 84 and $81^{\circ} \mathrm{F}$ (29 and $\left.27^{\circ} \mathrm{C}\right)$, respectively. The total rainfall for July was 5.24 inches $(13.3 \mathrm{~cm})$ with $11 \mathrm{~d}$ receiving more than 0.1 inch $(0.25 \mathrm{~cm})$. The total rainfall for $\mathrm{Au}-$ gust was 5.17 inches $(13.1 \mathrm{~cm})$ with 9 $\mathrm{d}$ receiving more than 0.1 inch. The similar rainfall amounts in July and August indicate that rainfall was probably not involved with the differential survival of the CFL, NFL, or TEX.

\section{Conclusions}

TEX did not survive the summers in north Florida as well as the CFL and NFL ecotypes from Florida. Similar results were observed in 1998 by Norcini et al. (2001b). It was suspected that a pathogen could be responsible for the decline in TEX, and a differential susceptibility to the disease may have been responsible for the difference in survival later in the season. However, when black-eyed susan from all three seed sources were inoculated under greenhouse conditions with isolates of $F$. oxysporum, the most commonly isolated potential pathogen from the roots and stems of af- 
fected plants in 1999 (data not shown), less than $20 \%$ of the plants developed disease and there were no clear differences in response among plants from the three seed sources. Alfieri et al. (1994) in a compilation of pathogens isolated from plants in Florida, reported that a Fusarium spp. was isolated from diseased Rudbeckia hirta. Eaker (1997) recovered F. oxysporum from Rudbeckia spp. in Georgia with what he called fusarium crown rot. Both of these isolations were from state diagnostic laboratories, but no further work was reported. Although F. oxysporum or some other pathogen may play an important role in the decline of TEX, it was not obvious from the greenhouse trials conducted.

Fumigation of soil with methylbromide-chloropicrin is a common practice in the production of many annual and perennial vegetable, fruit, and nut crops. These broad spectrum biocides are very effective at killing most soil borne plant pests, including nematodes, fungi, and weeds. However, because methyl bromide depletes atmospheric ozone, it is scheduled to be phased out in the United States by 2005 . Even though methyl bromide is an excellent soil fumigant, its ability to reduce disease caused by Fusarium spp. has been inconsistent. This inconsistency is not due to the limitations of the fumigant, but due to the ability of the Fusarium pathogens to rapidly reinvade the fumigated soil (Marois et al., 1983), especially when the field is strip fumigated as was done in this study. Strip fumigation, that is fumigation of the beds only, is the traditional method of fumigation for vegetable production, although strawberry fields are usually fumigated in their entirety. The ability of the pathogen to rapidly recolonize the fumigated soil is due to its high saprophytic activity in soils with little or no competition, a condition created by the broad spec- trum activity of the fumigant (Marois and Mitchell, 1981).

Plant parasitic nematodes have also been implicated as playing a possible role in the decline of stands of black-eyed susan. Although it is reported that black-eyed susan is not affected by root knot nematodes (Meloidogyne spp.) (Thetford and Kinloch, 1999), high populations of the spiral nematode (Scutellonemaspp.) were associated with a more rapid stand decline (Norcini et al., 2001b). Methyl-bromide-chloropicrin provides excellent control of nematodes and it is unlikely that in these field studies soil borne plant parasitic nematodes played any role in the rate of survival of the plantings. We conclude that the impact of soilborne nematodes was not responsible for the more rapid decline of TEX in Florida reported here.

A successful stand establishment is critical for an effective wildflower program. Although the preference in

Table 1. Effect of fumigation and irrigation on the survival of black-eyed susan.

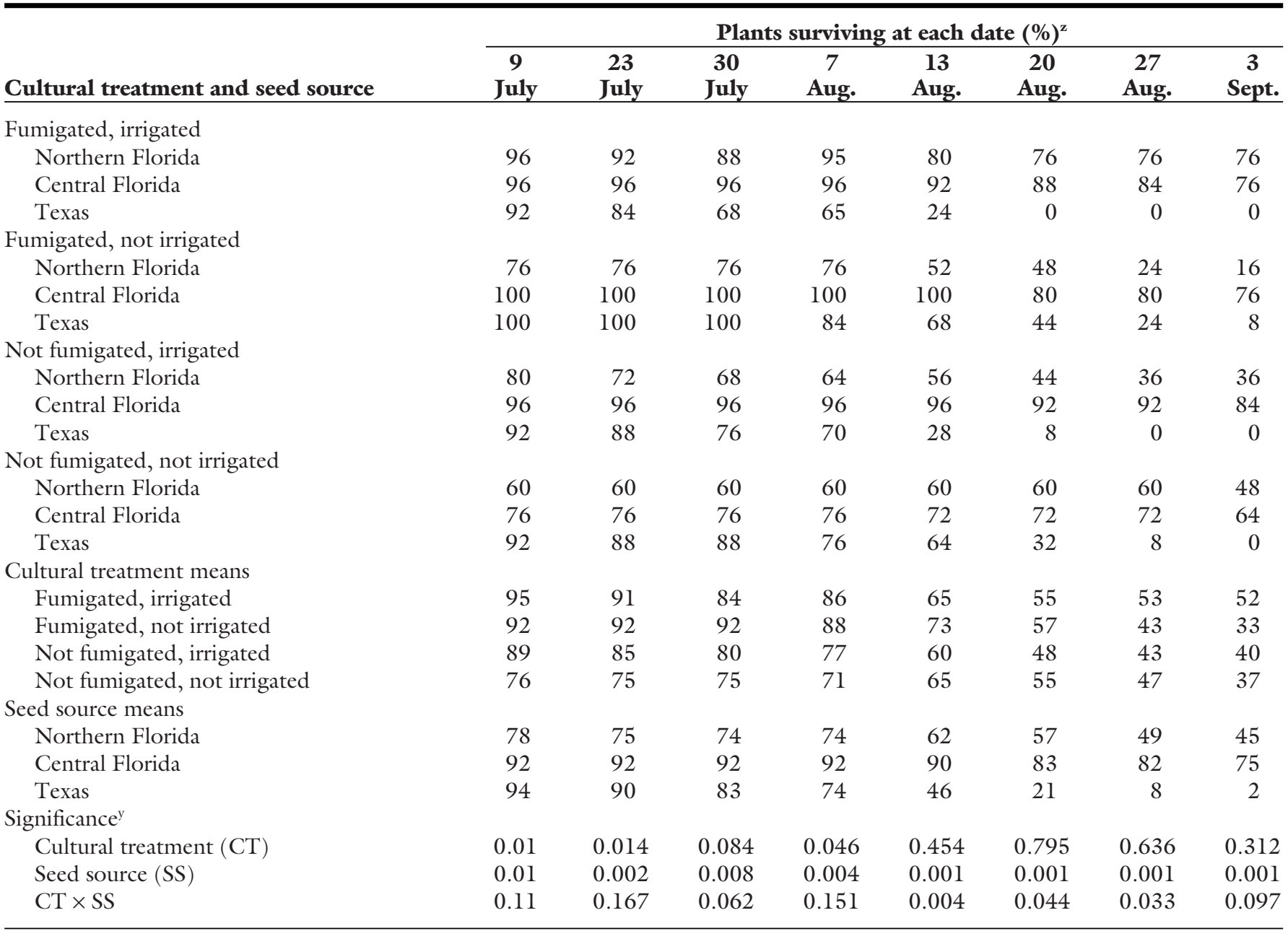

${ }^{z}$ Percent survival was based on number of plants still alive of the 25 plants ( 5 plots of 5 plants each) planted.

y Level of significance for main and interactive effects as determined by analysis of variance. 
Florida is to use a low input establishment procedure, some states use irrigation and soil fumigants to assure a successful stand. To determine if the survival of the ecotypes could be affected by growing conditions, blackeyed susan were planted in fumigated or nonfumigated and irrigated and nonirrigated plots. Although the initial survival of the plants was positively affected by both fumigation and irrigation, the long term survival of the plants was determined by seed source, not the conditions under which they were grown. The TEX population collapsed in August, whereas CFL and NFL survived through the season. We also observed that NFL was not as successful during the initial stand establishment, but that once the plants were established their rate of survival was not significantly different than CFL but better than TEX. In these trials there was no benefit of the additional inputs of irrigation and fumigation.

There was little difference in air temperature, soil temperature, and rainfall between July and August. This would indicate that the rapid decline in TEX was not dependent upon its differential response to these environmental conditions as a whole. The pathogen we are dealing with is not highly virulent and it acting alone may not be sufficient to cause widespread plant decline. Hence the interaction of this fungus with specific abiotic stresses under more controlled conditions needs to be investigated to determine the reasons for differential survival among CFL, NFL, and TEX. It is also possible that TEX is just a shorter season population.

Since TEX has larger and more blooms than CFL and NFL (Norcini et al., 2001b) it may be the seed source of choice for plantings where a shortterm display is desired. However, CFL and NFL provide longer term sustainability as was noted previously (Norcini et al., 2001b).

\section{Literature cited}

Alfieri, S.A., K.R. Langdon, J.W. Kimbrough, and C. Wehlburg. 1994. Diseases and disorders of plants in Florida. Div. Plant Ind., Gainesville, Fla., Bul. No. 14.

Beckwith D.D. 1991. Characterization of juvenility and photoperiodic responses of Rudbeckia hirta originating from different latitudes. MS thesis. Va. Polytech. Inst. and State Univ., Blacksburg.

Booth, C. 1971. The genus Fusarium. Commonwealth Mycol. Inst., Surrey, England.

Celik, M. 1996. Photoperiod and gibberellic acid effects on juvenility and flowering of Rudbeckia hirta. MS thesis. Miss. State Univ., Miss.

Eaker, T. 1997. Homeowner IPM Clinic Report. Univ. Ga. 4 Sept. 2002, <http:// www.ces.uga.edu/agriculture/plantpath/

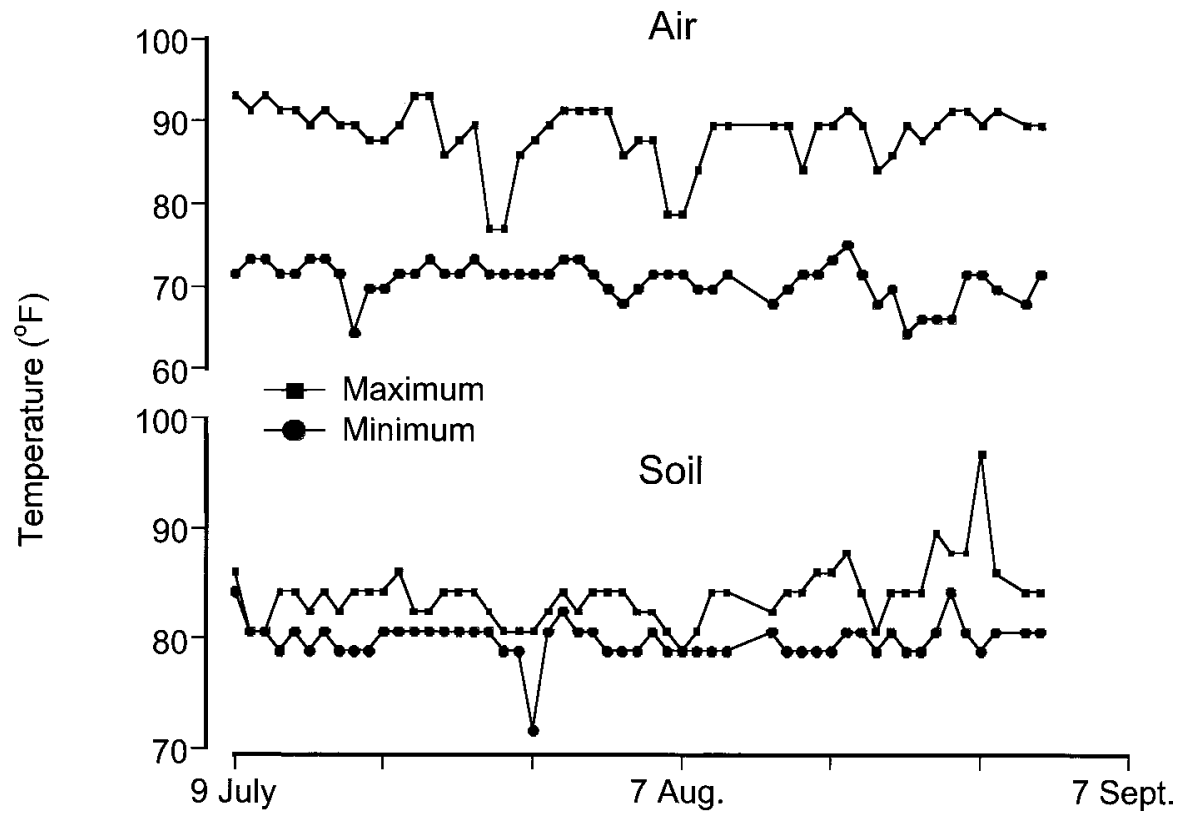

docs/IPMClinic/rptaug97.html>.

Marois, J.J. and D.J. Mitchell. 1981. Effect of fungal communities on the pathogenic and saprophytic activities of Fusarium oxysporum f. sp. radicis-lycopersici. Phytopathology 71:1251-1256.

Marois, J.J., M.T. Dunn, and G.C. Papavizas. 1983. Reinvasion of fumigated soil by Fusarium oxysporum f. sp. melonis. Phytopathology 73:680-684.

Norcini, J.G., J.H. Aldrich, L.A. Halsey, and J.G. Lilly. 1998. Seed source affects performance of six wildflower species. Proc. Fla. State Hort. Soc. 111:4-9.

Norcini, J.G., J.H. Aldrich, and F.G. Martin. 200la. Seed source effects on growth and flowering of Coreopsis lanceolata and Salvia lyrata. J. Environ. Hort. 19:212215 .

Norcini, J.G., M. Thetford, K.A. KlockMoore, M.L. Bell, B.K. Harbaugh, and J.H. Aldrich. 2001b. Growth flowering, and survival of black-eyed susan from different regional seed sources. HortTechnology 11:26-30.

Norcini, J.G., D.J. Zimet, C. Maura, S. Pfaff, and M.A. Gonter. 1999. Seed production of a Florida ecotype of black-eyed susan. Fla. Agr. Expt. Sta. Circ. 1226.

Rickett, H.W. 1967. Wildflowers of the United States. vol. 2. The southeastern states. McGraw-Hill, New York.

Thetford, M. and R.A. Kinloch. 1999. Galling response of herbaceous and woody landscape species grown in Meloidogyne incognita- and $M$. arenaria-infested soils. Univ. Fla.-Inst. Food Agr. Sci., W. Fla. Res. Educ. Ctr., Milton, Res. Rpt. 199908.

U.S. Department of Agriculture-NRCS. 2001. The PLANTS database. version 3.1. Natl. Plant Data Ctr., Baton Rouge, La. 20 Feb. 2002, <http://plants.usda.gov>.

Wunderlin, R.P. 1998. Guide to the vascular plants of Florida. Univ. Press Fla., Gainesville.
Fig. 1. Daily high and low air and soil temperatures during July and August 2001 at the study site located at the North Florida Research and Education Center, Quincy; ${ }^{\circ} \mathrm{C}$ $=5 / 9\left({ }^{\circ} \mathbf{F}-32\right)$. 